\title{
Helicobacter pylori promotes hepatic fibrosis in the animal model
}

\author{
Moon-Jung Goo ${ }^{1}$, Mi-Ran Ki ${ }^{1}$, Hye-Rim Lee ${ }^{1}$, Hai-Jie Yang ${ }^{1}$, Dong-Wei Yuan ${ }^{1}$, Il-Hwa Hong ${ }^{1}$, Jin-Kyu Park', \\ Kyung-Sook Hong ${ }^{1}$, Jung-Youn Han ${ }^{1}$, Ok-Kyung Hwang ${ }^{1}$, Dong-Hwan Kim', Sun-Hee Do ${ }^{2}$, Ronald D Cohn ${ }^{3}$ and \\ Kyu-Shik Jeong ${ }^{1}$
}

Helicobacter pylori infection has been reported to be very common in patients with chronic liver diseases, including cirrhosis. To elucidate the pathological effect of $\mathrm{H}$. pylori infection on the progression of hepatic fibrosis, C57BL/6 mice and Sprague-Dawley rats were orally inoculated with $\mathrm{H}$. pylori, and hepatic fibrosis was induced with carbon tetrachloride $\left(\mathrm{CCl}_{4}\right)$ administration. We observed the histopathological changes and the presence of $H$. pylori genes by PCR in the liver. Significant increase in the fibrotic score as well as in serum alanine aminotransferase and aspartate aminotransferase levels was shown in the $\mathrm{CCl}_{4}+\mathrm{H}$. pylori group compared with that in the $\mathrm{CCl}_{4}$-treated group. Compared with the $\mathrm{CCl}_{4}{ }^{-}$ treated group, $\alpha$-smooth muscle actin and transforming growth factor- $\beta 1$ were enhanced; however, senescence marker protein-30, a multifunctional protein protecting hepatocytes against oxidative stress and apoptosis, was suppressed in the $\mathrm{CCl}_{4}+\mathrm{H}$. pylori group. The $16 \mathrm{~S}$ rRNA $(400 \mathrm{bp}$ ) was demonstrated by PCR for $\mathrm{H}$. pylori genes from genomic DNA extracted from the liver, and $H$. pylori-infected mice showed $93.8 \%$ (15 of 16) seropositivity by contrast with seronegativity in all $H$. pylori-noninfected mice. In addition, immunohistochemical study against $H$. pylori showed positive antigen fragments in the liver of the infected groups. Consequently, our data suggest that $H$. pylori infection could be an important contributing infectious factor to the development of liver cirrhosis.

Laboratory Investigation (2009) 89, 1291-1303; doi:10.1038/labinvest.2009.90; published online 7 September 2009

KEYWORDS: Helicobacter pylori; hepatic fibrosis; liver; senescence marker protein 30; 16S rRNA

Helicobacter pylori is well known as an important pathogen that results in chronic gastritis associated with the development of peptic ulcer disease, atrophic gastritis and gastric cancer. ${ }^{1}$ Recently, evidence showing a possible association between $H$. pylori infection in the human stomach and chronic liver diseases is emerging. ${ }^{2-4}$ Many serological studies have found that patients with hepatitis have an increased H. pylori infection rate. ${ }^{3,5}$ Moreover, the prevalence of H. pylori in patients with cirrhosis has been reported to be remarkably higher than in non-cirrhotic patients. ${ }^{6,7}$ Helicobacter-like DNA that showed a high similarity to $H$. pylori and enterohepatic Helicobacter species was detected in the liver by PCR. ${ }^{8,9}$ Taken together, these observations support the idea that $H$. pylori infection may have a critical role in the pathogenesis of various liver disorders. Hepatic cirrhosis is clinically very important as high risk conditions underline the development of hepatocellular carcinoma (HCC), leading to a high rate of morbidity and mortality. ${ }^{10}$ Several factors such as toxins, viruses, oxidative stress, necrosis, apoptosis and growth factors are responsible for the activation of resting hepatic stellate cells (HSCs) which have an important role in the pathogenesis of hepatic cirrhosis. The transformation of quiescent HSC into myofibroblast-like cells with the expression of cytoskeletal protein $\alpha$-smooth muscle actin $(\alpha$-SMA) initiates the chronic process of hepatic fibrosis, finally leading to the fatal stage of liver cirrhosis. ${ }^{11}$

A few papers have recently reported that $H$. pylori caused liver damages as an independent etiological factor, and that the gene belonging to it was demonstrated by PCR in mice. ${ }^{12}$ After being infected with $H$. pylori for 2 years, the mice developed primary HCC, and bacteria were shown by immunohistopathological staining. ${ }^{13}$ Although some data

\footnotetext{
${ }^{1}$ Department of Pathology, College of Veterinary Medicine, Kyungpook National University, Daegu, Republic of Korea; ${ }^{2}$ Department of Clinical Pathology, College of Veterinary Medicine, Konkuk University, Seoul, Republic of Korea and ${ }^{3}$ Department of Pediatrics and Neurology, Mckusick-Nathans Institute of Genetic Medicine, Johns Hopkins University, School of Medicine, Baltimore, MD, USA

Correspondence: Dr K-S Jeong, DVM, PhD, Department of Pathology, Kyungpook National University, College of Veterinary Medicine, no. 1370, Sangyeok-dong, Daegu, Buk-ku 702-701, Republic of Korea.
}

E-mail: jeongks@knu.ac.kr

Received 7 March 2009; revised 1 July 2009; accepted 2 July 2009 
suggest that $H$. pylori caused the cytopathic effect in a liver and HCC cell line in vitro, ${ }^{14,15}$ the role of $H$. pylori infections in the development of chronic liver diseases including cirrhosis in humans is still not well characterized. Therefore, our study aimed at investigating the role of $H$. pylori infection in the pathogenesis of the damaged liver tissues by carbon tetrachloride $\left(\mathrm{CCl}_{4}\right)$ administration in the murine model.

\section{MATERIALS AND METHODS Bacterial Strains}

H. pylori strain ATCC 43504 (American Type Culture Collection, a cagA ${ }^{+}, v a c A$ s1-m1 strain) and Sydney Strain (SS1, a $\operatorname{cag} A^{+}$, vacA s2-m2 strain $)^{16}$ were used in this study. Each H. pylori was grown on Meuller Hinton ( $\mathrm{MH}$ ) agar supplemented with an antibiotic mixture and incubated for $48 \mathrm{~h}$ at $37^{\circ} \mathrm{C}$ under microaerophilic conditions. The cells were harvested in phosphate-buffered saline (PBS), centrifuged at $2000 \times g$ for $10 \mathrm{~min}$, and resuspended in PBS at a final concentration of $10^{9}$ colony-forming units $(\mathrm{CFU}) / \mathrm{ml}$. In all experiments, cultures grown for $48 \mathrm{~h}$ on $\mathrm{MH}$ agar plates were used.

\section{Animals and Experimental Design Animals}

SPF female Sprague-Dawley rats 14 weeks of age and 8-weekold SPF female C57BL/6 mice, absent from Helicobacter bills and Helicobacter hepaticus, were housed under clean conditions, fed a commercial diet and given water ad libitum. All animals were managed under the animal guideline of NIH, USA. Experimental liver fibrosis was produced by intraperitoneal administration of $10 \% \mathrm{CCl}_{4}$ in olive oil at $1.0 \mathrm{ml} / \mathrm{kg}$ thrice a week, and normal control animals received the same volume of vehicle (olive oil; $1.0 \mathrm{ml} / \mathrm{kg}$ b.w, i.p.) at the same time. After an overnight fast, each animal was intragastrically inoculated either with a suspension of H. pylori containing $10^{9} \mathrm{CFU} / \mathrm{ml}$ or sham infected with an equal volume of PBS using gastric intubation needles.

\section{Experimental design-1}

The rats $(n=24)$ were divided into the following three groups: (1) normal controls $(n=8)$, (2) only $\mathrm{CCl}_{4}$-treated group $(n=8)$ and (3) $\mathrm{CCl}_{4}+H$. pylori group $(n=8)$. The only $H$. pylori group was not involved considering the low relationship between $H$. pylori and the liver in this preliminary study. $\mathrm{CCl}_{4}$ was administered on three separate occasions over a 5 -day period for 8 weeks to induce liver fibrosis. ${ }^{17}$ From week 1, when constructing the animal model of hepatic injury was begun, the H. pylori strain ATCC 43504, $1.0 \mathrm{ml}$ of inoculum per rat, was inoculated orally in a daily alternative manner with $\mathrm{CCl}_{4}$ treatment. Rats were killed at the end of the eighth week; from each rat, blood samples were collected from the inferior vena cava, and the liver and stomach were removed.

\section{Experimental design-2}

The mice $(n=32)$ were divided into the following four groups: (1) normal controls $(n=8),(2)$ only $H$. pylori-infected group $(n=8)$, (3) only $\mathrm{CCl}_{4}$-treated group $(n=8)$ and (4) $\mathrm{CCl}_{4}+H$. pylori group $(n=8)$. The only $H$. pylori group was inserted to observe the independent effect of $H$. pylori on the liver. $\mathrm{CCl}_{4}$ was administered for 15 weeks as a previously described regimen to induce liver fibrosis. ${ }^{18,19}$ In these animal models, $\mathrm{CCl}_{4}$ treatment was conducted after the first week, when inoculation of the mice with $H$. pylori was initiated. Mice were infected with $H$. pylori strain SS1, $0.2 \mathrm{ml}$ of inoculum per mouse, killed at the end of the sixteenth week and then their organs were collected as described above.

\section{Histopathology}

For histopathological analysis, samples of the liver and stomach were fixed in $10 \%$ neutralized buffered formalin, processed using the standard method and embedded in paraffin. Sections of $4-\mu \mathrm{m}$ thickness were then stained with hematoxylin and eosin (H\&E) or with Azan staining for collagen fiber. Liver samples were scored on histopathological changes including fibrosis using the scoring system proposed by Mendler et $a l^{20}$ and additional parameters related to hepatic injury were analyzed with Periodic Acid Schiff (PAS) stain and oil-red $\mathrm{O}$ stain.

\section{Immunohistochemistry}

Sectioned liver samples were assessed by the routine immunohistochemistry method, using the monoclonal mouse antibodies of $\alpha$-SMA (Sigma, Saint Louis, MO, USA), polyclonal rabbit antibodies of transforming growth factor- $\beta 1$ (TGF- $\beta 1$ ) (Santa Cruz Biotechnology, CA, USA), polyclonal rat antibodies of SMP30 (obtained from Achito Ishigami), polyclonal rabbit antibodies of H. pylori (Dako, Glostrup, Denmark) and monoclonal mouse antibodies of proliferating cell nuclear antigen (PCNA) (Santa Cruz Biotechnology). Immunoreactive materials were visualized with avidin-biotin-peroxidase complex solution using an $\mathrm{ABC}$ Kit (Vector Laboratories, Burlingame, CA, USA) with 3,3-diaminobenzidine (Zymed Laboratories, San Francisco, CA, USA). Terminal deoxynucleotidyl transferase-mediated nick-end labeling staining was performed using a commercial apoptosis detection kit (Roche Diagnostics GmbH, Penzberg, Germany). The number of positively stained cells of a total of 1000 hepatocytes in the $\times 200$ field was quantified by counting, and the results were reported as the mean percentage of positively stained cells compared with the total hepatocytes.

\section{Immunoblotting}

Electrophoresis of proteins was performed routinely on sodium dodecyl sulfate gel containing polyacrylamide (SDSPAGE) gels using standard methods. For immunoblotting, 50-100 $\mu \mathrm{g}$ of purified protein per lane were run on an SDSPAGE $10 \%$ gel and transferred into a PVDF membrane 
(Schleicher \& Schuell, Dassel, Germany). $\alpha$-SMA (Sigma), TGF- $\beta 1$ (Santa Cruz Biotechnology) and SMP30 (obtained from Akihito Ishigami) were detected using a commercially enhanced chemiluminescence system (ECL, Amersham, Buckinghamshire, UK), and exposed to medical X-ray film (Kodak, Tokyo, Japan).

\section{Biochemical Serum Transferase Assessment}

The serum alanine aminotransferase (ALT), aspartate aminotransferase (AST), alkaline phosphatase, total bilirubin and cholesterol levels were measured using an automized instrument (Konelab 60I Analyser, Konelab, Finland).

\section{Hepatic Hydroxyprolin Content}

Hepatic hydroxyprolin content was determined using the method described by Jeong et al, ${ }^{21}$ with some modifications. In brief, frozen liver tissue $(50 \mathrm{mg}$ for mouse and $200 \mathrm{mg}$ for rat) was hydrolyzed in $4 \mathrm{ml}$ of $6 \mathrm{~N} \mathrm{HCl}$ at $120^{\circ} \mathrm{C}$ for $30 \mathrm{~min}$. The hydrolysate was filtered, and then $50 \mu$ l of filtrate was evaporated under vacuum. Dried samples were dissolved in $125 \mu \mathrm{l}$ of isopropanol and incubated with $62.5 \mu \mathrm{l}$ chloramines-T/citrate buffer ( $\mathrm{pH} 6.0$ ) at $25^{\circ} \mathrm{C}$ for $4 \mathrm{~min}$. Freshly prepared $750 \mu \mathrm{l}$ of Ehrlich's reagent was added and then incubated at $60{ }^{\circ} \mathrm{C}$ for an additional $25 \mathrm{~min}$. Absorbance at $560 \mathrm{~nm}$ was recorded using a spectrophotometer (Tecan, Salzburg, Austria). The absorbance value of each liver was taken to represent the hydroxyproline content of the tissue, and this was expressed in $\mu \mathrm{g}$ hydroxyproline per $\mathrm{g}$ of tissue (wet weight).

\section{Serum Anti-H. Pylori Antibody}

The enzyme-linked immunosorbent assay (ELISA) method was applied to detect anti-H. pylori IgG antibodies. Flat bottom 96-well plates (Nunc, Denmark) were coated with $0.5 \mu \mathrm{g}$ of $\mathrm{H}$. pylori-whole cell lysate antigen in $100 \mu \mathrm{l}$ of $20 \mathrm{mM}$ carbonate buffer ( $\mathrm{pH} 9.6)$ and then incubated overnight at $4{ }^{\circ} \mathrm{C}$. The plates were washed three times with $0.05 \%$ Tween 20/Tris-buffered saline (TBS), and the nonspecific binding sites were blocked with $1 \%$ skim milk for $1 \mathrm{~h}$ at room temperature. Serum samples (diluted to 1:100) were added in duplicate, and the plates were incubated for $2 \mathrm{~h}$ at $37^{\circ} \mathrm{C}$. The plates were washed as described above and then incubated with horseradish peroxidase-conjugated anti-mouse $\mathrm{IgG}$ (Cell Signaling Technology, Beverly, MA, USA) for mouse samples and anti-rat IgG (Santa Cruz Biotechnology) for rat samples, respectively, at a dilution of 1:5000 in 0.05\% Tween 20/TBS for $1 \mathrm{~h}$ at $37^{\circ} \mathrm{C}$. The plates were once again washed, then developed using a 1-Step Ultra TMB-ELISA Kit (Pierce, Rockford, IL, USA). Upon optimal color development, the reaction was stopped by adding $2 \mathrm{M}$ sulfuric acid to the plates. Optical densities $(450 \mathrm{~nm})$ were measured using a plate reader (Tecan). The absorbance value was presented as mean \pm s.d.

\section{DNA Extraction}

In all, $60-80 \mathrm{mg}$ of ground frozen liver tissues under liquid nitrogen were transferred into a sterile $1.5-\mathrm{ml}$ Eppendorf tube. The samples were incubated overnight at $50{ }^{\circ} \mathrm{C}$ in $500 \mu \mathrm{l}$ lysis buffer $(50 \mathrm{mM}$ Tris $\mathrm{pH} \quad 8.0,100 \mathrm{mM} \mathrm{NaCl}$, $100 \mathrm{mM}$ EDTA, pH 8.0, $0.1 \%$ SDS) containing $0.5 \mathrm{mg} / \mathrm{ml}$ proteinase K (Sigma). Proteins were extracted with equal volume of phenol-chloroform-isoamyl alcohol in a ratio of 25:24:1 (Sigma) and centrifuged at $1410 \times g$ for $5 \mathrm{~min}$ at $10{ }^{\circ} \mathrm{C}$, followed by transferring the supernatants into a new tube. Subsequently, an equal volume of chloroform-isoamyl alcohol in a ratio of 24:1 (Sigma) was added, centrifuged at $1410 \times g$ for $5 \mathrm{~min}$ at $10^{\circ} \mathrm{C}$ and the supernatants were transferred into a new tube. The genomic DNA in the supernatant was recovered by precipitation with ethanol, followed by centrifuging at $20800 \times \mathrm{g}$ at $4{ }^{\circ} \mathrm{C}$ for $5 \mathrm{~min}$. The precipitated DNA was washed in $70 \%$ ethanol and dried overnight. Finally, DNA was resuspended in $500 \mu$ l ultra pure water and measured in Qubit Fluorometer (Invitrogen, The Netherlands). In all, $40 \mathrm{ng}$ of DNA extract was used in each PCR reaction.

\section{PCR Amplification}

DNA extracted from the liver tissue samples were amplified by Helicobacter genus-specific 16S rRNA primers described by Fox et al: ${ }^{4}$ sense primer: $5^{\prime}$-GCT ATG ACG GGT ATC C-3' (C97F); antisense primer: $5^{\prime}$-GAT TTT ACC CCT ACA CCA$3^{\prime}$ (C98R). The forward and reverse primers amplified a product of $\sim 400$ bp. ${ }^{4}$ A volume of $2 \mu \mathrm{l}$ of $40 \mathrm{ng}$ DNA and $1 \mu \mathrm{l}$ of 20 pmol from each primer were added to the PCR PreMix Kit (Bioneer, Daejon, Korea) containing $250 \mu \mathrm{M}$ of each dNTPs, $40 \mathrm{mM} \mathrm{KCl}, 1.5 \mathrm{mM} \mathrm{MgCl}, 1 \mathrm{U}$ of Taq polymerase and $10 \mathrm{mM}$ Tris- $\mathrm{HCl}(\mathrm{pH} 9.0)$. The final mixture was amplified after a PCR cycle program: initial activation of the Taq-polymerase at $94{ }^{\circ} \mathrm{C}$ for $10 \mathrm{~min}$, denaturation at $94^{\circ} \mathrm{C}$ for $30 \mathrm{~s}$, annealing at $55^{\circ} \mathrm{C}$ for $30 \mathrm{~s}$, extension at $72^{\circ} \mathrm{C}$ for $30 \mathrm{~s}$ ( 35 cycles) and a final extension step at $72{ }^{\circ} \mathrm{C}$ for $5 \mathrm{~min}$. The $40 \mathrm{ng}$ amplified products were loaded onto $1.5 \%(\mathrm{w} / \mathrm{v})$ agarose (SeaKem LE Agarose, Cambrex, Bio Science Rockland, Rockland, ME, USA) gels containing ethidium bromide, and the PCR product sizes were estimated by comparison with a 100-bp DNA size marker (MBI Fermentas, Vilnius, Lithuania). H. pylori strain SS1 was used as a positive control and ultra pure water was used as the negative control at each amplification event. Bands were visualized under UV light.

\section{Statistical Analysis}

When experiments included only two groups, the two-tailed $t$-test was used. When the experimental design included more than two groups, statistical differences were determined by analysis of variance. Comparisons between particular groups were then made by the Bonferroni test, keeping an overall probability of error lesser than 0.05 . 


\section{Results}

\section{Hepatic Fibrosis in the $\mathbf{C C L}_{\mathbf{4}}+\mathbf{H p}$ Livers}

Histological analysis using H\&E stain showed marked microvesicular and macrovesicular fatty changes with thin fibrotic septa in the $\mathrm{CCl}_{4}$-treated livers. Bile duct epithelial proliferation in thick fibrotic septa and a more severe mononuclear inflammatory cell infiltration were observed in the $\mathrm{CCl}_{4}+\mathrm{Hp}$ livers (Figure 1a). Liver collagen content was determined by morphometry using Azan staining (Figure 1b), and histological findings were assessed and then scored with regard to the fibrotic stage (Table 1 ). $\mathrm{CCl}_{4}$ induced long collageneous septa connecting the central veins across the liver parenchyma at 8 weeks in rats and at 16 weeks in mice. Interestingly, $H$. pylori infection during $\mathrm{CCl}_{4}$ treatment remarkably increased the development of liver fibrosis as compared with $\mathrm{CCl}_{4}$ alone in both rats and mice. The $\mathrm{CCl}_{4}+\mathrm{Hp}$ livers of experimental animals showed a marked increase in the collagen band intersecting the liver parenchyma to form bridging fibrotic septa, which progressed into pseudolobules (Figure 1b). To confirm these results, total hydroxyprolin concentration was evaluated in both species of animals (Table 1). The hydroxyprolin level was significantly higher in the $\mathrm{CCl}_{4}+\mathrm{Hp}$ livers than in the only $\mathrm{CCl}_{4}$-treated $(P<0.05)$ livers. This result corresponded to the severity of fibrosis in both sets of animal models.

\section{Effects of $\boldsymbol{H}$. Pylori on Biochemical Factors in the $\mathrm{CCL}_{4}$ - Treated Livers}

As shown in Table 1, H. pylori infection significantly contributed to the $\mathrm{CCl}_{4}$-induced increase in AST and ALT levels in both mouse and rat models. In rats, plasma alkaline phosphatase and total bilirubin activities in the $\mathrm{CCl}_{4}+\mathrm{Hp}$ groups $(151.4 \pm 85.1 \mathrm{IU} / \mathrm{l}$ and $0.48 \pm 0.44 \mathrm{mg} / \mathrm{dl}$, respectively, $P<0.05)$ were markedly elevated than in the $\mathrm{CCl}_{4}$ groups $(78.3 \pm 31.1 \mathrm{IU} / \mathrm{l}$ and $0.22 \pm 0.13 \mathrm{mg} / \mathrm{dl}$, respectively), whereas plasma total cholesterol was significantly reduced $\left(79.8 \pm 36.0 \mathrm{mg} / \mathrm{dl}\right.$ in $\mathrm{CCl}_{4}$ groups and $56.2 \pm 13.5 \mathrm{mg} / \mathrm{dl}$ in $\mathrm{CCl}_{4}+\mathrm{Hp}$ groups, $\mathrm{P}<0.05$ ) (data not shown), indicating a more severe hepatic injury.

\section{Expression of Chronic Liver Damage Markers in the $\mathrm{CCL}_{4}+$ Hp Livers}

We performed immunohistochemical staining and immunoblotting using chronic liver injury markers (Figure 2). a
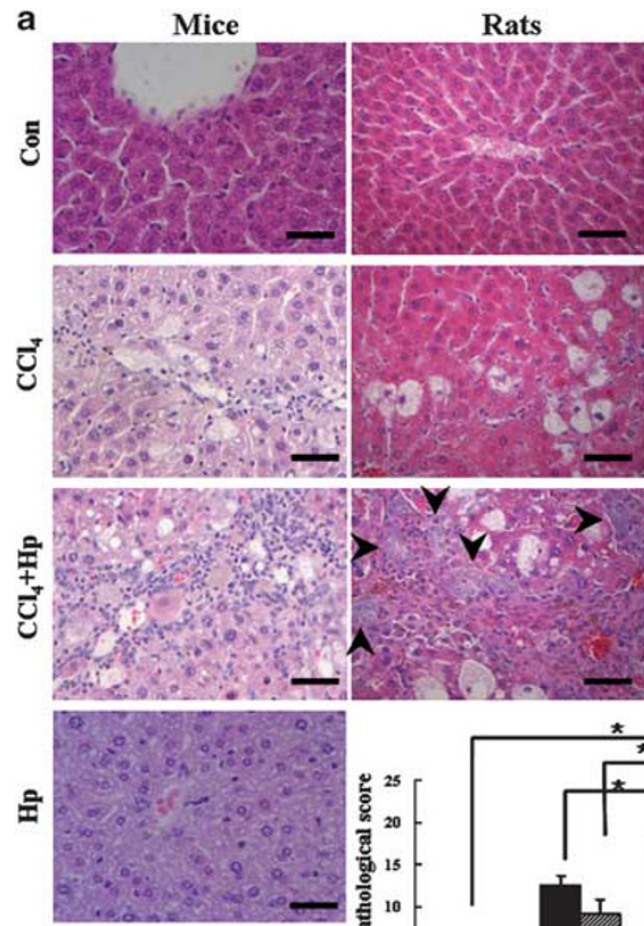

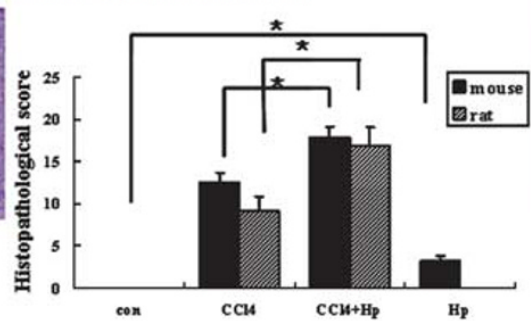

b
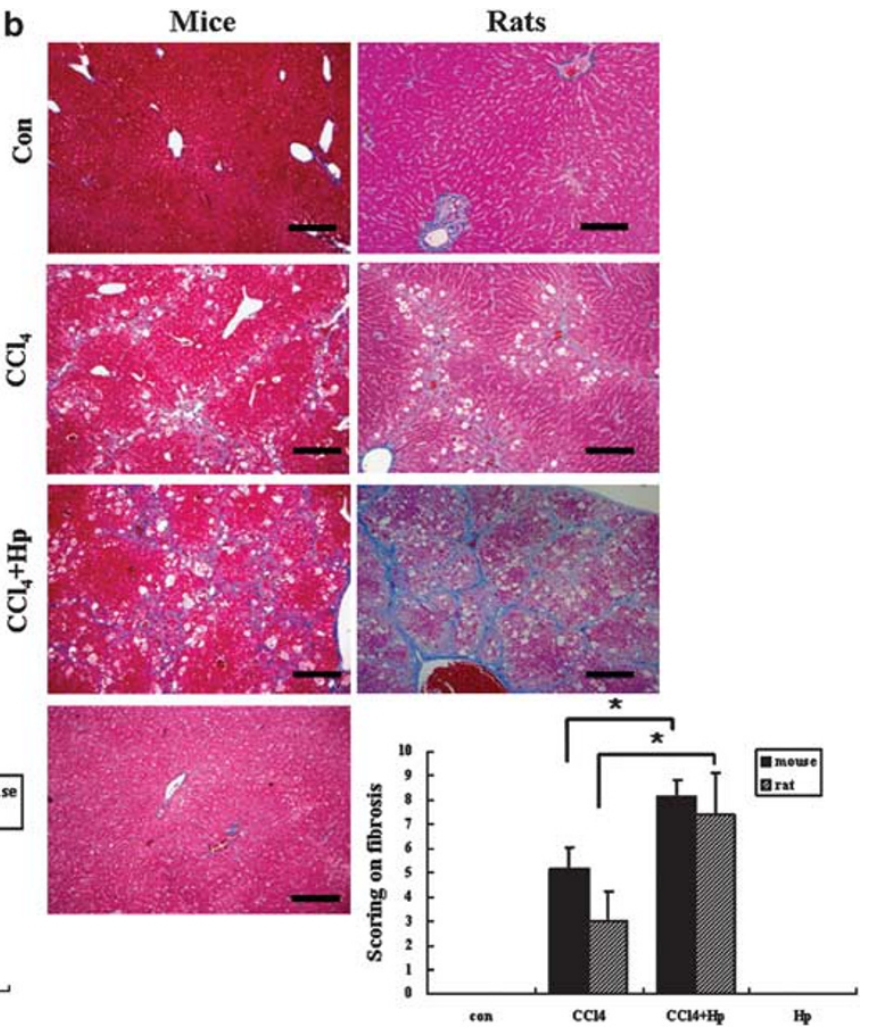

Figure 1 Histopathological changes in the livers. (a) The livers were stained by H\&E staining and the pathological scores were represented as mean \pm s.d. ${ }^{\star} P<0.05$. In $\mathrm{CCl}_{4}$-treated groups, hepatocytes with cytoplasmic microvesicular and macrovesicular fatty changes were accompanied with fine collagenous fibers surrounding degenerative hepatocytes. In $\mathrm{CCl}_{4}+\mathrm{Hp}$ groups, perivenular zones showed extensive collagen deposition with a prominent increase in activated hepatic stellate cells (HSCs) and small lymphocytes. Bile duct (arrow) proliferation in the fibrotic septa was also observed. In a $H$. pylori-infected group, the hepatocytes contained various sized cytoplasmic vacuoles. Scale bar, $50 \mu \mathrm{m}$. (b) The liver was stained by Azan staining and scoring on fibrosis was represented as mean \pm s.d. ${ }^{\star} P<0.05$. The marked increase in hepatic fibrosis showing micronodular formation by interconnective fibrotic septa in the $\mathrm{CCl}_{4}+\mathrm{Hp}$ group, in comparison with activity in the $\mathrm{CCl}_{4}$ group is noted. Scale bar, $200 \mu \mathrm{m}$. 
Table 1 Effects of infection of $\boldsymbol{H}$. pylori on fibrosis grade, serum biochemical tests and tissue HYP levels in experimental animals

\begin{tabular}{lllll}
\hline $\begin{array}{l}\text { Animals and } \\
\text { groups }\end{array}$ & $\begin{array}{l}\text { Fibrosis } \\
\text { grade }\end{array}$ & AST (IU/l) & ALT (IU/I) & HYP $(\mu \mathrm{g} / \mathrm{g})$ \\
\hline
\end{tabular}

Rats

$\begin{array}{lcccl}\text { Con } & 0 & 112.9 \pm 23.0 & 32.4 \pm 7.9 & 223.6 \pm 8.3 \\ \mathrm{CCl}_{4} & 3 \pm 1.2^{\dagger \dagger} & 569.6 \pm 291.5^{\dagger \dagger} & 440.4 \pm 24.3^{\dagger \dagger} & 271.4 \pm 43.7^{\dagger} \\ \mathrm{CCl}_{4}+\mathrm{Hp} & 7.4 \pm 1.7^{*} & 2408 \pm 2003.8^{*} & 1454.5 \pm 814.0^{*} & 326.8 \pm 62.0^{*}\end{array}$

Mice

$\begin{array}{lcccl}\text { Con } & 0 & 61.6 \pm 5.4 & 21.4 \pm 3.20 & 190.8 \pm 53.0 \\ \mathrm{CCl}_{4} & 5.1 \pm 0.9^{\dagger \dagger} & 1364.8 \pm 724.1^{\dagger \dagger} & 2340 \pm 1027.5^{\dagger \dagger} & 269.3 \pm 40.3^{\dagger \dagger} \\ \mathrm{CCl}_{4}+\mathrm{Hp} & 8.1 \pm 0.7^{* *} & 3085 \pm 674.4^{*} & 5038 \pm 1006.2^{*} & 321.9 \pm \pm 46.7^{*} \\ \mathrm{Hp} & 0 & 79.5 \pm 7.8 & 20 \pm 1.4 & 204.9 \pm 57.5\end{array}$

ALT, alanine aminotransferase; AST, aspartate aminotransferase; HYP, hydroxyproline.

Results are expressed as the mean \pm s.d.

${ }^{*} P<0.05 ;{ }^{* * P}<0.01$ vs $\mathrm{CCl}_{4}$ group.

${ }^{\dagger} P<0.05 ;{ }^{\dagger \dagger} P<0.01$ vs control group.

The expression of $\alpha$-SMA is a characteristic feature of activated HSCs and this is considered as a marker for exacerbation of hepatic fibrosis and related cellular events. In the control livers, $\alpha$-SMA-immunoreactive cells were detected mainly in the portal area as elements of vascular walls. Focal accumulated $\alpha$-SMA-positive cells around the central vein branches and the portal area were detected in only the $\mathrm{CCl}_{4}$ treated livers. In the livers of the $\mathrm{CCl}_{4}+\mathrm{Hp}$ group, more intensely stained $\alpha$-SMA-positive HSCs associated with vascular walls were observed in the liver parenchyma (Figure 2a). $\alpha$-SMA was hardly detected in the normal liver by immunoblotting. In contrast, $\alpha$-SMA expression was dramatically increased in the $\mathrm{CCl}_{4}+\mathrm{Hp}$ livers when compared with that in the $\mathrm{CCl}_{4}$-only treated animals that exhibited slightly increased levels when compared with control animals (Figures $2 \mathrm{~b}$ and c). This result completely correlated with our immunohistochemical observation in both species of the murine model.

Immunohistochemistry for triggering hepatic fibrosis was performed in the mouse and rat livers using anti-TGF- $\beta 1$ antibodies (Figure 3a). Macrophages expressing TGF- $\beta 1$ were infiltrated at the chronic injured area constituted with fibrotic septa around the central vein in the $\mathrm{CCl}_{4}$-treated livers. $H$. pylori infection markedly increased the recruit of macrophages showing a positive reaction with TGF- $\beta 1$ in the $\mathrm{CCl}_{4}$ treated livers. The weak activity of TGF- $\beta 1$ was detected by immunoblotting assay in controls and in the H. pylori-infected livers in a similar level, although it was difficult to detect by immunohistochemistry. Immunoblotting data showed that TGF- $\beta 1$ was expressed significantly higher in the
$\mathrm{CCl}_{4}+\mathrm{Hp}$ livers than in the only $\mathrm{CCl}_{4}$-treated livers (Figures $3 \mathrm{~b}$ and c). Overall, the expression of $\alpha$-SMA and TGF$\beta 1$ in the liver sections was modulated by orogastric $H$. pylori infection in the hepatic fibrosis-induced murine model.

\section{Expression of SMP30 as an Anti-Oxidative Stress Marker in the $\mathrm{CCL}_{\mathbf{4}}+\mathrm{Hp}$ Livers}

Jung et al suggested that increased oxidative condition result in the downregulation of the SMP30 gene expression and in the subsequent decrease in SMP30 protein. ${ }^{16} \mathrm{H}$. pylori alone decreased the expression of SMP30, mainly located around the central vein, in the livers compared with that in the control livers on immunohistochemical staining (Figure 4a). The reduction in SMP30 in the $\mathrm{CCl}_{4}$-treated livers was remarkably enhanced by $H$. pylori infection, suggesting an increased magnitude of oxidative stress (Figure 4a). Correlative trends were shown on immunoblotting (Figures $4 \mathrm{~b}$ and c). H. pylori infection significantly decreased SMP30 expression in hepatocytes when compared with the control livers as shown through the immunohistochemical study. $\mathrm{CCl}_{4}$ more severely reduced SMP30 levels in the livers than did H. pylori. Significant downregulation of SMP30 in the $\mathrm{CCl}_{4}$-treated livers with concomitance of $\mathrm{H}$. pylori infection in immunoblotting precisely agreed with the findings of immunohistochemical study. This was particularly true for mice infected with $H$. pylori that showed significantly decreased SMP30 expression in the $\mathrm{CCl}_{4}$-treated livers.

\section{Immunohistochemical Identification of $\boldsymbol{H}$. Pylori Infection}

Gram-negative curved bacterium was found in colonies obtained from incubation of the gastric mucosa (Figure 5b). Similar organisms in the gastric pits of infected animals were confirmed to be $H$. pylori-antigen positive by immunohistochemical stain using anti- $H$. pylori antibodies (Figure 5a). Immunohistochemical stain for $H$. pylori showed positively reacted particles within the $H$. pylori-infected liver tissue, especially in Kupffer cells existing along the adjacent sinusoid, and occasionally in hepatocytes (Figures $5 \mathrm{c}$ and $\mathrm{d}$ ). Immunopositivity for $\mathrm{H}$. pylori was $75 \%$ (6 of 8 ) in the $H$. pylori-infected mouse livers without $\mathrm{CCl}_{4}$ administration, and $62.5 \%$ (5 of 8) in the H. pylori-infected mouse livers with $\mathrm{CCl}_{4}$ administration (data not shown). Consequently, these immunohistochemical data support the results of the PCR reaction, indicating the presence of the $H$. pylori gene in the infected liver tissue.

\section{Determination of $\boldsymbol{H}$. Pylori Infection}

Overall, $75 \%$ of the inoculated mice (12 of 16 ) had a typical H. pylori colony from plated homogenized stomach on $\mathrm{MH}$ agar plate with antibiotics, and Gram-negative spiral bacterium was found in these colonies by gram staining. Mice showing $H$. pylori colonies had organisms colonizing the gastric pit of the stomach on histopathological analysis (Figures $5 \mathrm{a}$ and $\mathrm{b}$ ). There was no evidence of cross-infection 
a
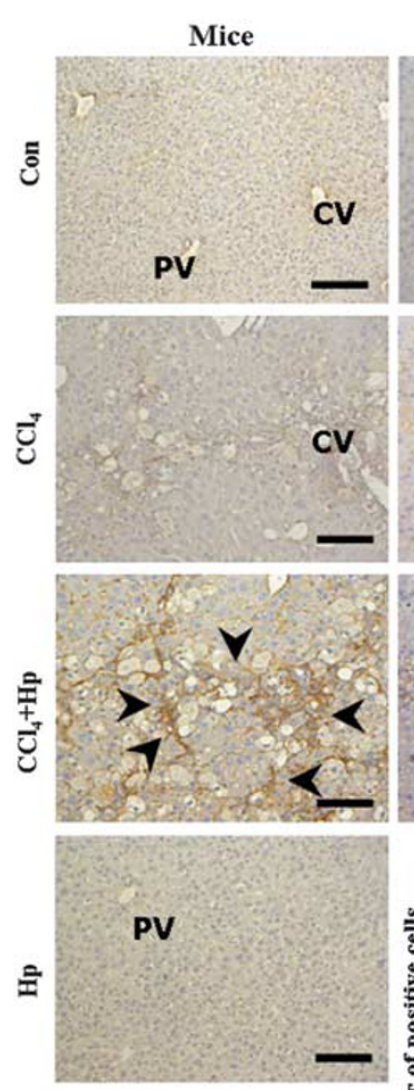
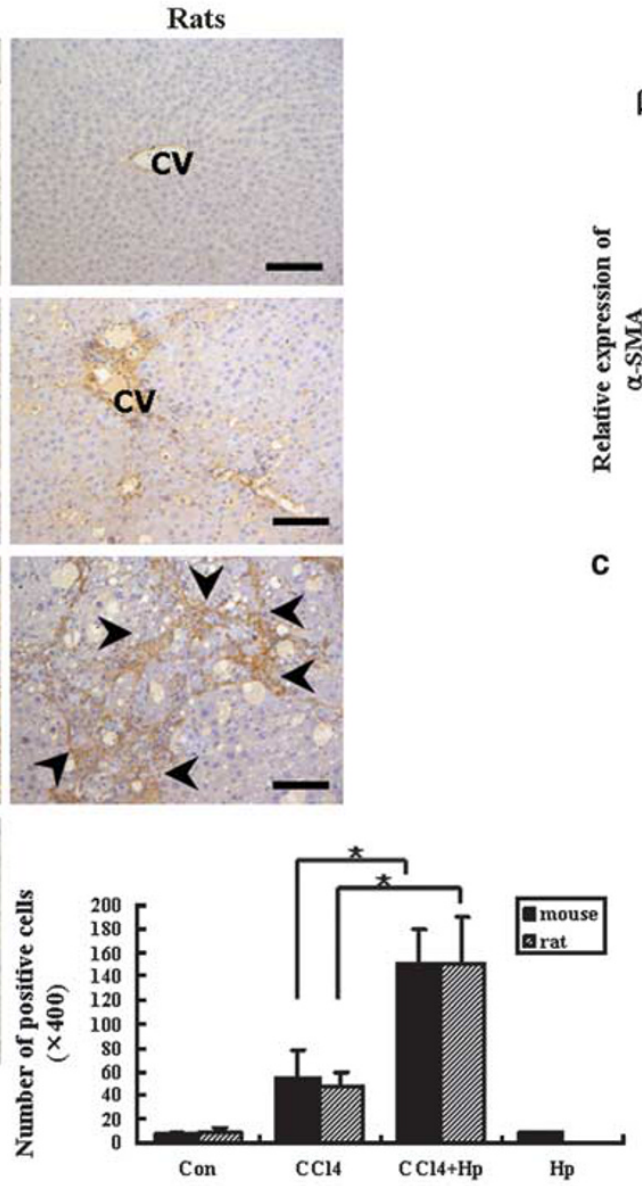

C b
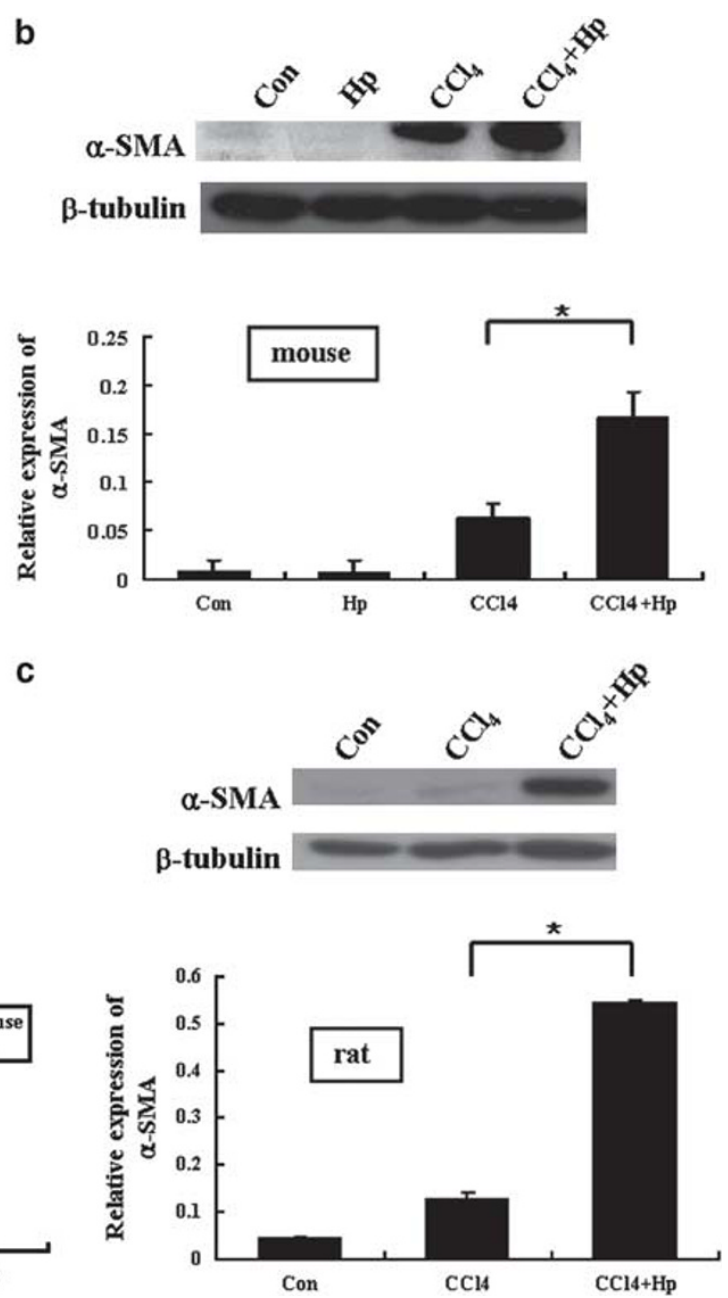

Figure $2 \alpha$-SMA expression of the livers. (a) The livers were stained for $\alpha$-SMA and the number of positive cells was represented as mean \pm s.d. ${ }^{\star} P<0.0001$. Normal expression of myofibroblasts (MFBs) was identified by $\alpha$-SMA-positive staining and was restricted to the vascular walls in the portal area and the central vein. Plentiful activated hepatic stellate cells (HSCs) (arrowhead), strongly positive, in the liver parenchyma showed increased continuity with each other in $\mathrm{CCl}_{4}+\mathrm{Hp}$ compared with those in $\mathrm{CCl}_{4}$ groups. $\mathrm{CV}$, central vein; PV, portal vein; Scale bar, $100 \mu \mathrm{m}$. (b and c) $\alpha$-SMA expression in liver tissues was assessed by immunoblotting. Histographic representation of relative expression of $\alpha$-SMA in the liver tissues was measured and expressed as mean \pm s.d. ${ }^{\star} P<0.005$ compared with only $\mathrm{CCl}_{4}$-treated group. Upregulation of $\alpha$-SMA activities in the liver infected by $H$. pylori accompanied with the administration of $\mathrm{CCl}_{4}$ was observed in comparison with only $\mathrm{CCl}_{4}$-treated livers.

as $H$. pylori was not present in any of the 16 sham-infected mice. To examine whether $H$. pylori could be detected in the liver tissue, DNA extracted from the liver tissue samples in mice were tested by PCR amplification using primers for the Helicobacter genus-specific 16S rRNA (Figure 6). The size of all PCR products corresponded to the expected size of $400 \mathrm{bp}$. The number of positive samples in the only $H$. pylori-infected group was $87.5 \%$ (7 of 8 ) and in the $\mathrm{CCl}_{4}+\mathrm{Hp}$ group, $100 \%$ ( 8 of 8 ) of samples were positive (data not shown).

\section{Detection of Serum IgG Anti-H. Pylori}

The level of serum anti- $H$. pylori total IgG in the H. pylori-infected groups is shown in Table 2. Sera were collected at week 8 in rats and at week 16 in mice, and the antibody response was determined by ELISA. We detected specific $H$. pylori-reactive IgG antibodies in $50 \%$ of the infected rats ( 4 of 8$)$ and in $87.5 \%$ of the infected mice ( 14 of 16). In mice, increased levels of the total IgG antibody titers against $H$. pylori were observed in the $H p$ group $(P=0.03)$ and in the $\mathrm{CCl}_{4}+\mathrm{Hp}$ group $(P=0.005)$ in comparison with the control group. To investigate the relationship between $\mathrm{CCl}_{4}$ administration and rate of $\mathrm{H}$. pylori infection, levels of IgG antibodies against $H$. pylori were compared as well as the sera of the only $H$. pylori-infected subjects and different groups accompanied with $\mathrm{CCl}_{4}$ administration. Interestingly, $\mathrm{H}$. pylori infection in the $\mathrm{CCl}_{4}{ }^{-}$ treated group resulted in significantly increased specific serum $\operatorname{IgG}(P=0.02)$, in comparison with the only $H$. pylori-infected group. Taken together, it was confirmed that $H$. pylori-infected groups showed seropositivity in contrast to seronegativity in all $H$. pylori-noninfected groups in both rats and mice. 
a

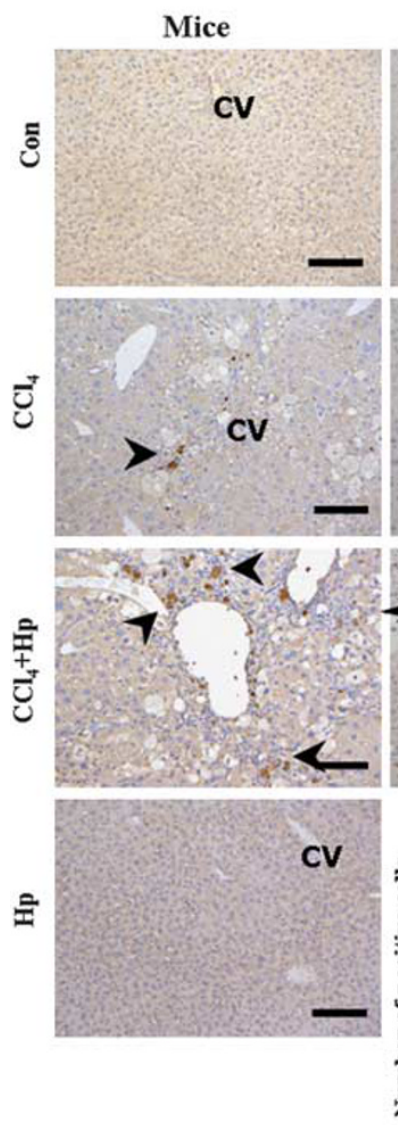

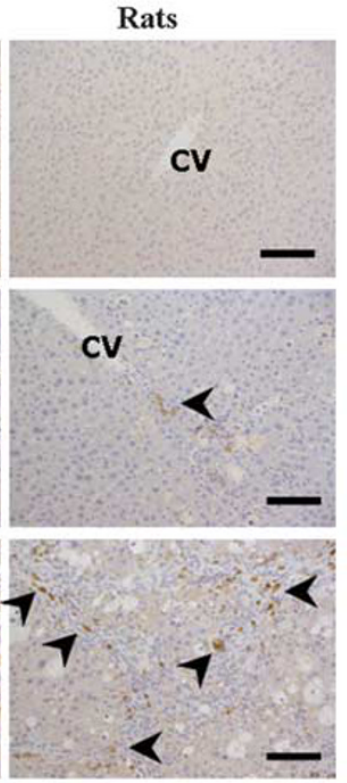

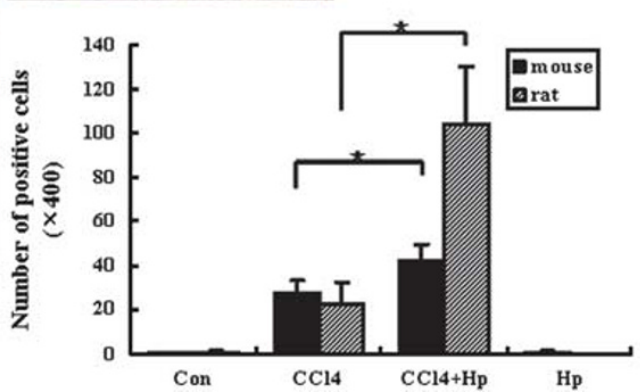

C b
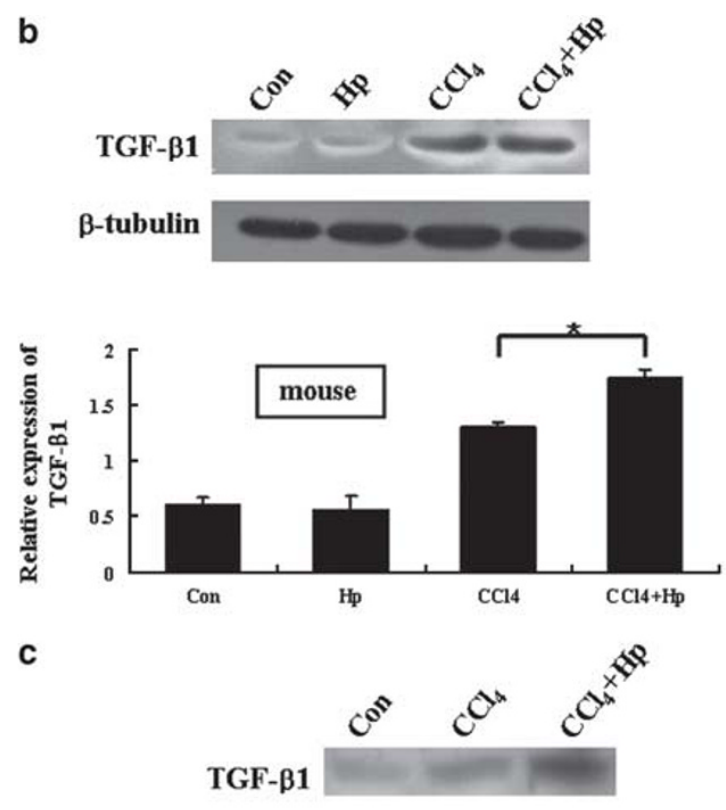

B-tubulin

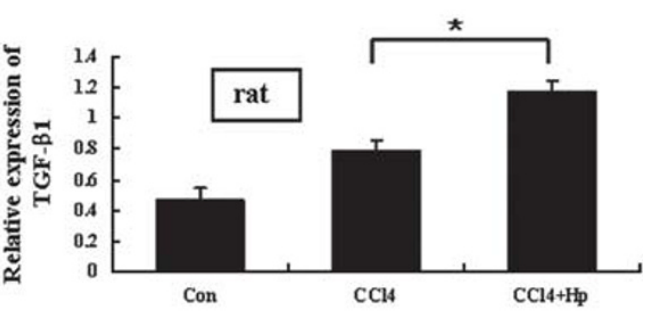

Figure 3 TGF- $\beta 1$ expression in the livers. (a) The livers were stained for TGF- $\beta 1$ and the number of positive cells was represented as mean \pm s.d. ${ }^{\star} P<0.0001$. No expressed cell was identified by TGF- $\beta 1$-positive staining in the control and $\mathrm{Hp}$ groups. In $\mathrm{CCl}_{4}$ groups, TGF- $\beta 1$-positive macrophages (arrowhead) can be seen in the fibrotic septa emerging from the central vein (CV). Remarkably increased macrophages (arrowhead), strongly positive, along the increased thick fibrotic septa are observed in $\mathrm{CCl}_{4}+\mathrm{Hp}$ groups. CV, central vein; scale bar, $100 \mu \mathrm{m}$. (b and c) TGF- $\beta 1$ expression in the liver tissues was assessed by immunoblotting. Histographic representation of relative expression of TGF- $\beta 1$ in the liver tissues was measured and expressed as mean \pm s.d. ${ }^{\star} P<0.005$ compared with only $\mathrm{CCl}_{4}$-treated group. Upregulation of TGF- $\beta 1$ activities in the liver infected by $\mathrm{H}$. pylori accompanied by the administration of $\mathrm{CCl}_{4}$ was observed compared with only $\mathrm{CCl}_{4}$-treated liver.

\section{Histopathological Assessment of the $\boldsymbol{H}$. Pylori-Infected Livers}

As shown in Figure 7, the H. pylori-infected livers showed extensively degenerative changes such as cytoplasmic vacuolation and increased binucleation, although the foci of hepatocytic death were rarely noted. This vacuolation showed mild lipid droplets by oil-red O staining (Figure 8). In addition, PAS stain showed reduction in glycogen storage in the H. pylori-infected livers (Figure 8). In the H. pylori-infected mice, the percentage of binucleated hepatocytes was significantly greater than in the respective control mice (Figure 7). To determine changes in hepatocyte proliferation and apoptosis, the expression of PCNA was assessed and the TUNEL method conducted, respectively, in the liver (Figure 7). Differences in PCNA levels among the groups were also statistically significant $(P<0.05)$. PCNA-positive cells, including binucleated hepatocytes, markedly increased in the H. pylori-infected livers, in comparison with the control livers, whereas apoptosis assessed by TUNEL-positive count showed no difference between the two groups (Figure 7).

\section{Discussion}

We previously reported the development of primary biliary cirrhosis in a C57BL/6 mouse infected with $H$. pylori over 1 year $^{22}$ and another author's experimental study on healthy C57BL/6 mice showed that $H$. pylori infection for 8 months led to hepatic inflammation characterized by the infiltration of lymphocytes. ${ }^{12}$ In this study, we established a hepatic fibrosis model with repeated administration of $\mathrm{CCl}_{4}$. To demonstrate the role of $H$. pylori in the progression of hepatic fibrosis, we constructed two separate experimental designs using two different rodent models to observe a potentially different effect between pre-infection and post 
a
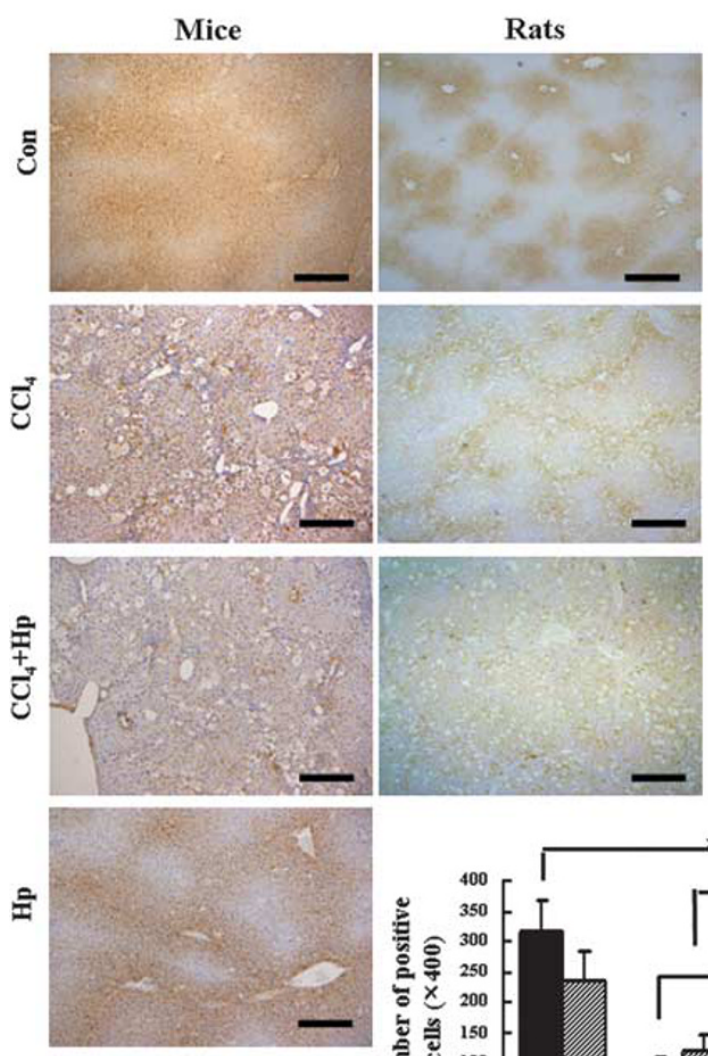
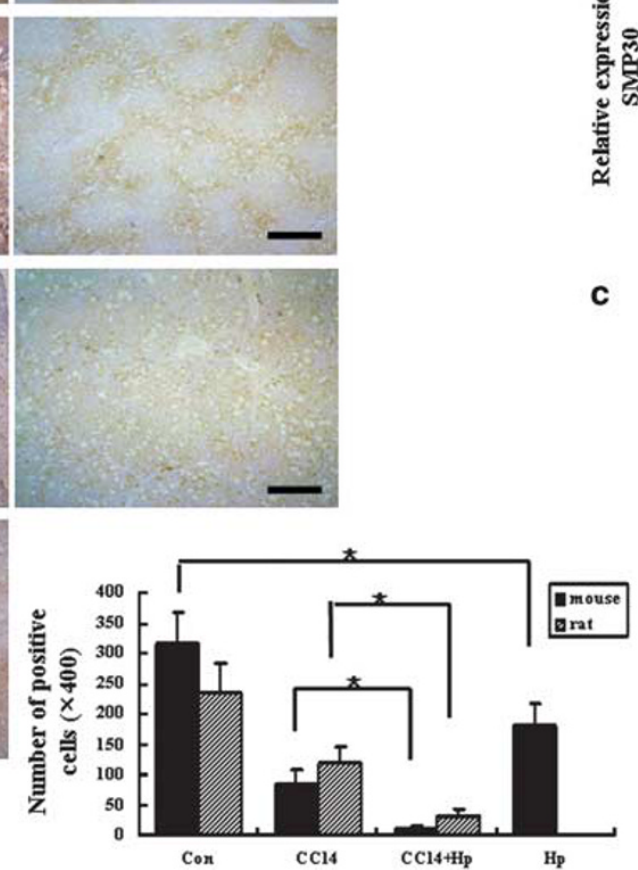

C b
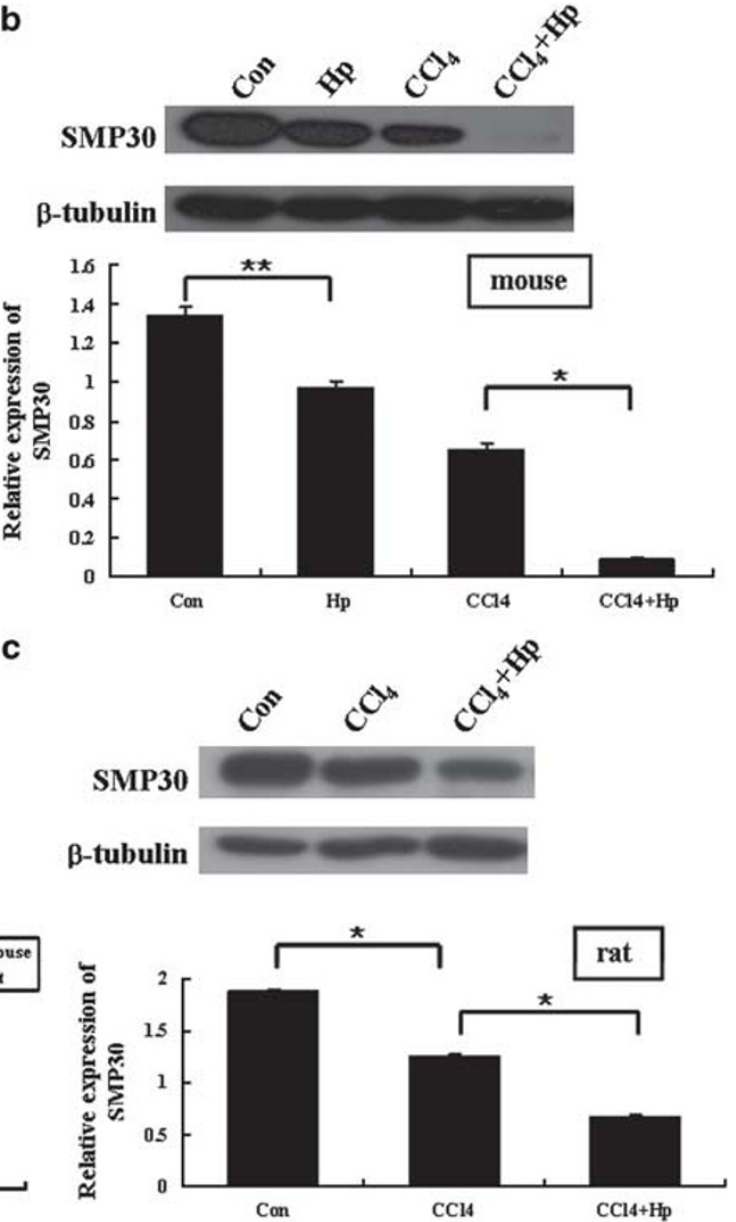

Figure 4 SMP30 expression in the livers. (a) Livers were stained for SMP30 and the number of positive cells was represented as mean \pm s.d. ${ }^{\star} P<0.0001$. Strongly expressed normal hepatocytes within the cytoplasm and nucleus were identified around the hepatic central vein in the control group. Positively reacted cells in the $\mathrm{CCl}_{4}+\mathrm{Hp}$ group remarkably decreased in comparison with those in $\mathrm{CCl}_{4}$ group. The area of positive immunoreaction around the central vein was significantly reduced in the Hp group compared with the normal control group. Scale bar, $400 \mu \mathrm{m}$. (b and c) SMP30 expression in the liver tissues was assessed by immunoblotting. Histographic representation of relative expression of SMP30 in the liver tissues was measured and expressed as mean \pm s.d. ${ }^{*} P<0.005$ compared with only $\mathrm{CCl}_{4}$-treated group. Downregulation of SMP30 activities in the liver infected by $\mathrm{H}$. pylori accompanied by the administration of $\mathrm{CCl}_{4}$ was observed in comparison with only $\mathrm{CCl}_{4}$-treated liver.

infection of $H$. pylori after exposure to $\mathrm{CCl}_{4}$ administration. In the preliminary study with rats, we did not include the only $H$. pylori group as we speculated whether $H$. pylori influenced liver injury induced by $\mathrm{CCl}_{4}$. First, ATCC $43504 \mathrm{H}$. pylori strains which were not recognized as strong antigens was inoculated after the induction of liver injury to rats, from which the results suggested a possible role of $H$. pylori on liver fibrosis. Using the results obtained from the rat model, we experimented with the mouse model to inspect the independent role of $H$. pylori in the liver. To investigate whether pre-infection causes the same phenomenon, the SS1 H. pylori strain, much used as the standard mouse-adapted strain for experimental infection, was used for mice. Mice and rats were killed when known as inducing fibrotic stage by $\mathrm{CCl}_{4}$ administration. ${ }^{17-19}$

H. pylori infection for 4 months caused functional and morphological degenerative changes in hepatocytes, such as the depletion of glycogen particles, hydropic degeneration, binucleation and accumulation of numerous small fat droplets in our present research (Figures 7 and 8). These histological findings regarding hepatocytes suggest that $H$. pylori causes a disarrangement of hepatic architecture with some showing slight focal necrosis and inflammatory changes in spite of there being no severe hepatitis present in the liver samples used in this study (Figure 7). The hepatocyte in those degenerated liver samples is more vulnerable to external harmful stimuli. ${ }^{23}$ Consequently, another concomitant liver disorder may provide a synergistic combination of liver injury, such as steatosis, oxidative damages that aggravate liver injury. ${ }^{24}$ Therefore, microvesicular fatty changes in the $H$. pylori-infected liver could be susceptible to the oxidative stress, and then deteriorate hepatic damage on the basis of liver fibrosis induced by $\mathrm{CCl}_{4}$ administration. In addition, an increase in binucleated hepatocytes (Figure 7) indicates 

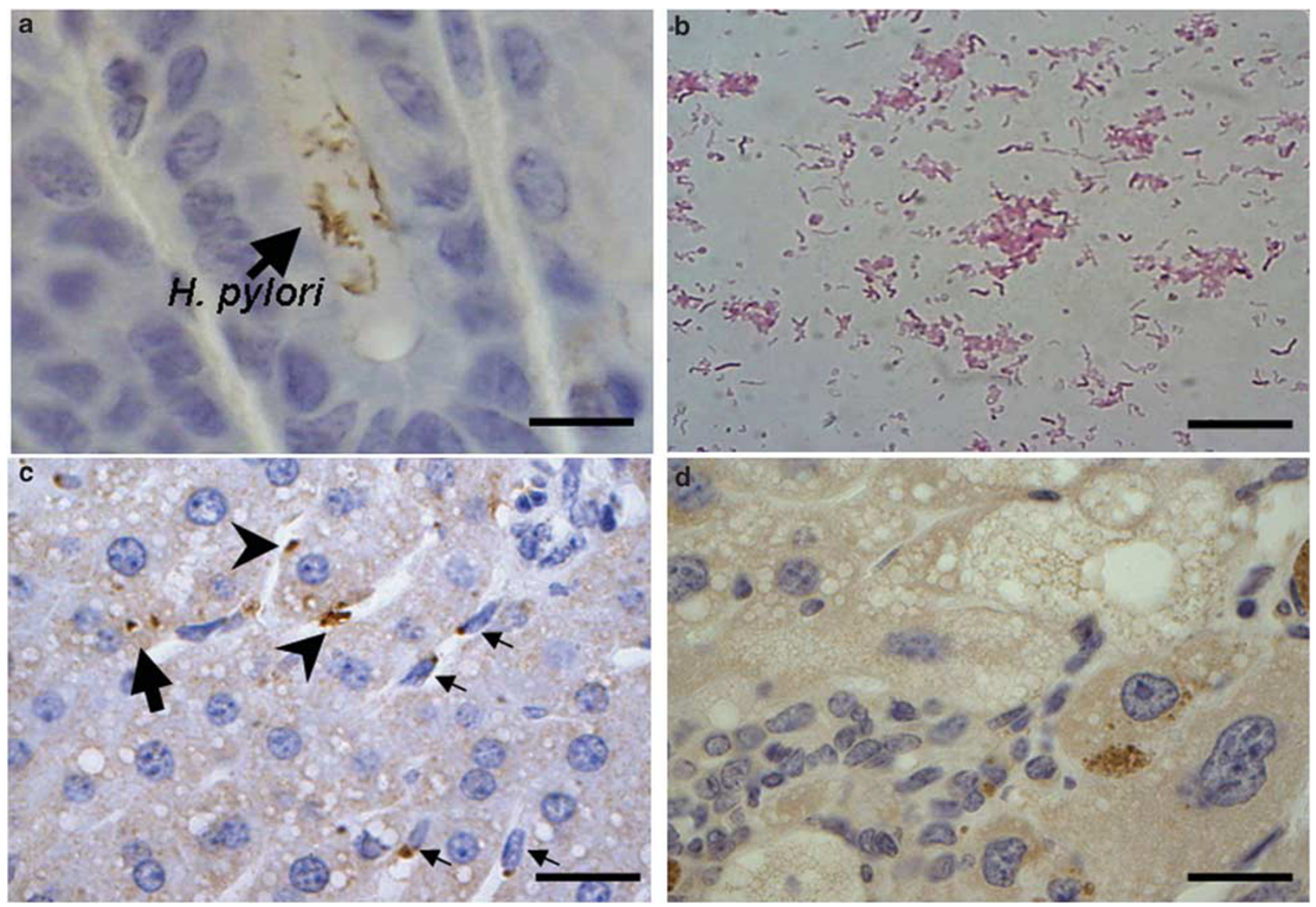

Figure 5 Demonstration of $H$. pylori in the stomach and liver tissues by immunohistochemistry (IHC) using antibodies for $H$. pylori and Gram stain. Colonization of gastric tissue by spiral or curved H. pylori was observed in a gastric pit by IHC for $H$. pylori (a). The small curved $H$. pylori with Gram negativity was observed in the colonies plated from gastric mucosa of $\mathrm{H}$. pylori-infected mice (b). IHC using antibodies for $\mathrm{H}$. pylori in the liver tissues that were only $\mathrm{H}$. pylori infected (c) and $\mathrm{H}$. pylori infected with $\mathrm{CCl}_{4}$ treatment (d). Positive immunoreactivity was observed along the hepatic sinusoid (arrowhead) and the intracytoplasm of hepatocyte (large arrow). Kupffer cells (small arrow) lining the sinusoid represent positive-reacted particles, may be phagocyted (c). Immunopositive particles were observed in the cytoplasm of degenerated hepatocyte (d). Scale bar, $20 \mu \mathrm{m}$.
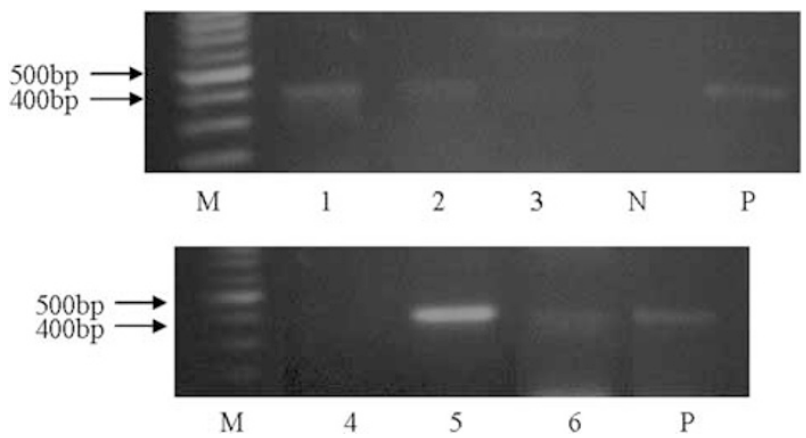

Figure 6 A schematic representation of the PCR products of the H. pylori DNA from H. pylori-infected mouse liver samples. Gel image showing amplification products of $16 \mathrm{~S}$ rRNA PCR with Helicobacter genus-specific $16 \mathrm{~S}$ rRNA primers at $400 \mathrm{bp}$. ' $\mathrm{M}$ ' represents $100-\mathrm{bp}$ molecular weight marker, and lanes ' $\mathrm{N}$ ' and ' $\mathrm{P}$ ' represent reaction negative control and positive control, respectively. Lanes 1 and 2 represent $H$. pylori-infected liver DNA samples without $\mathrm{CCl}_{4}$ treatment, whereas lane 3 represents the control liver. Lane 4 represents only $\mathrm{CCl}_{4}$-treated liver without $\mathrm{H}$. pyloriinfected DNA sample. Lanes 5 and 6 represent the $\mathrm{CCl}_{4}$-treated liver with H. pylori-infected DNA samples. pathological effects of $H$. pylori infection, as it suggests that under oxidative stress, the increase in binucleated hepatocytes can be caused either by a fusion of two hepatocytes with damaged cell membranes or by a regenerative process against hepatic damage. ${ }^{25}$ Immunohistochemistry for PCNA showed that increased binucleated cells were correlated with a positive reaction in hepatocytes of the $H$. pylori-infected livers, suggesting that hepatocytes proliferated against liver damage (Figure 7).

One study suggested that $H$. pylori infection may be related to increasing endotoxins (LPS) found in Gram-negative bacteria in patients with cirrhosis. ${ }^{26}$ Previous studies have described glycogen depletion in various infectious and pathological conditions, although the mechanism of depletion of liver glycogen stores in endotoxemia is still unclear. ${ }^{27}$ Histological findings in this study suggest a possible derangement of carbohydrate metabolism in rodents infected with $H$. pylori. Moreover, reductions in hepatic glycogen suggested increased glucose utilization and were consistent 
with the expected depletion of hepatic ATP after mitochondrial impairment, assuming that there was a consequent increase in energy production from glycolysis. Damaged mitochondria due to endotoxin result in hydropic degeneration in hepatocytes. ${ }^{28}$ Therefore, functional changes such as the depletion of hepatic glycogen could point to impending liver damage during $H$. pylori infection.

Remarkably, our findings indicate that $H$. pylori exacerbate the progression of hepatic injury from fibrosis to cirrhotic stage in the $\mathrm{CCl}_{4}$-treated liver. The degree of hepatocellular

Table $2 \boldsymbol{H}$. pylori-specific IgG antibody titers in sera

\begin{tabular}{|c|c|c|c|}
\hline \multirow[t]{2}{*}{$\begin{array}{l}\text { Animals } \\
\text { and groups } \\
(n=8)\end{array}$} & $\begin{array}{l}\text { H. pylori strain } \\
43504 \text { specific IgG } \\
\text { antibody titer }\end{array}$ & $\begin{array}{l}\text { Animals } \\
\text { and groups } \\
(n=8)\end{array}$ & $\begin{array}{l}\text { H. pylori strain } \\
\text { SS1 specific IgG } \\
\text { antibody titer }\end{array}$ \\
\hline & D $450 \mathrm{~nm}$ (mean \pm s.d & & OD $450 \mathrm{~nm}$ (mean \pm s.d.) \\
\hline
\end{tabular}

Rats

$$
\text { Con }
$$

$\mathrm{CCl}_{4}$

$0.1085 \pm 0.0063$

$0.121 \pm 0.0086$

$0.271 \pm 0.2589$

$\mathrm{CCl}_{4}+\mathrm{Hp}$
Mice

Con

$\mathrm{Hp}$

$\mathrm{CCl}_{4}$

$\mathrm{CCl}_{4}+\mathrm{Hp}$
$0.0283 \pm 0.0248$

$0.1957 \pm 0.2050^{*}$

$0.0414 \pm 0.0285$

$0.775 \pm 0.8198^{*, \dagger}$
OD, optical density.

Results are expressed as mean \pm s.d.

${ }^{\star} P<0.05$ compared with the noninfected control group, ${ }^{\dagger} P=0.02$ compared with the Hp group. injury was shown by a dramatic increase in serum levels of AST, ALT and hepatic hydroxyproline content, and the substantial extension of fibrous areas was confirmed by Azan staining. Biochemical markers on liver injury were significantly increased; morphological architecture was more severely destructed; and the fibrotic area was remarkably extended in $\mathrm{CCl}_{4}+\mathrm{Hp}$ rather than in only $\mathrm{CCl}_{4}$-administrated livers. Furthermore, the expression of fibrosis-related cytokine was significantly upregulated in the $\mathrm{CCl}_{4}+\mathrm{Hp}$ livers, compared with that in the $\mathrm{CCl}_{4}$ livers. Immunoblot analysis, which shows a significant correlation with immunohistochemical data, further confirmed this finding. TGF- $\beta$ has been shown to be a key profibrogenic cytokine, as it has a prominent role in the production of extracellular matrix by activated HSC. ${ }^{29}$ In particular, TGF- $\beta 1$, which is a well-studied mediator in hepatic fibrogenesis, promotes HSC transition into the myofibroblast ${ }^{29}$ and is involved in the formation of $\alpha$-SMA fiber formation in the myofibroblast. ${ }^{30}$

The major cellular mechanisms of $\mathrm{CCl}_{4}$ are suggested to produce free radicals, which damage the hepatocyte by causing lipid peroxidation and binding cell structures. ${ }^{31}$ Many studies have indicated that oxidative stress may represent a common link between chronic liver damage and hepatic fibrosis. ${ }^{32}$ Damaged hepatocytes, their membrane components, metabolites of toxic agents and infiltrating inflammatory cells activated Kupffer cells, and then these activated Kupffer cells released several important cytokines to act on the HSCs, which transited to myofibroblast-like cells with a remarkably increased capacity for collagen synthesis. ${ }^{29}$
A
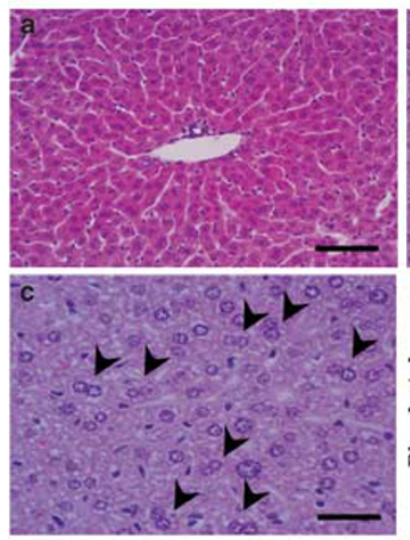
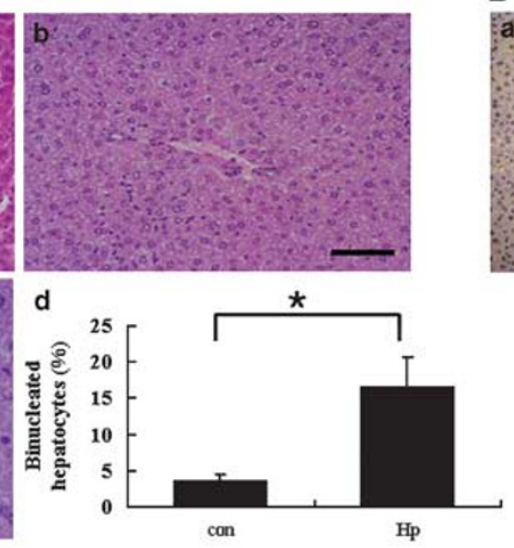

B
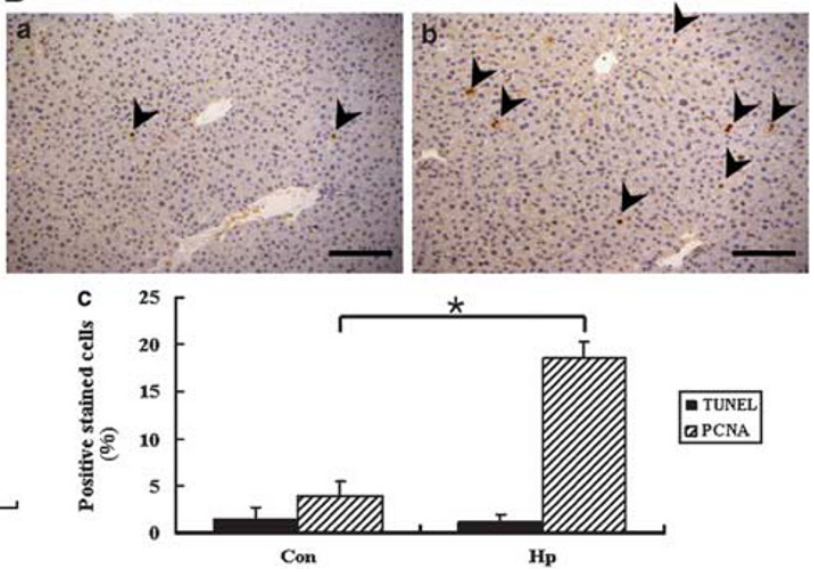

Figure 7 Histopathological findings of the $\mathrm{H}$. pylori-infected livers. (A) Histopathological changes by $\mathrm{H}$. pylori infection in the mouse liver tissues stained by hematoxylin-eosin staining. Normal mouse hepatocytes with eosinophilic cytoplasm were separated from the sinusoid (a). The $H$. pylori-infected mouse liver tissue showed compressed sinusoid by swollen hepatocytes with faint cytoplasm with vacuole (b). The H. pylori-infected mouse liver showed diffuse hepatocellular degeneration characterized by pale swollen hepatocytes with cytoplasmic rarefaction, anisokaryosis and binucleation (arrow) at high magnification (c). Scale bar: (a and b) $100 \mu \mathrm{m}$; (c) $20 \mu \mathrm{m}$. The number of binucleated hepatocytes significantly increased in $\mathrm{H}$. pylori-infected mice compared with that in the controls. ${ }^{*} P<0.001$ (d). (B) The expression of PCNA and TUNEL in normal and $H$. pylori-infected mouse liver. The normal liver showed nearly no activity for PCNA immunostain. Scale bar, $100 \mu \mathrm{m}$ (a). The H. pylori-infected liver showed increased immunopositive cells, especially binucleated hepatocytes, for PCNA antibody. Scale bar, $100 \mu \mathrm{m}(\mathbf{b})$. The number of TUNEL- and PCNA-positive cells was compared between the control and H. pyloriinfected groups (c). TUNEL indicates a nonsignificant difference between groups on the basis of Student's $t$-test $(P>0.05)$. The increase in PCNA-positive hepatocytes caused by $H$. pylori infection $(P<0.05)$ is noted. PCNA, proliferating cell nuclear antigen; TUNEL, terminal deoxynucleotidyl transferase-mediated nick-end labeling. 


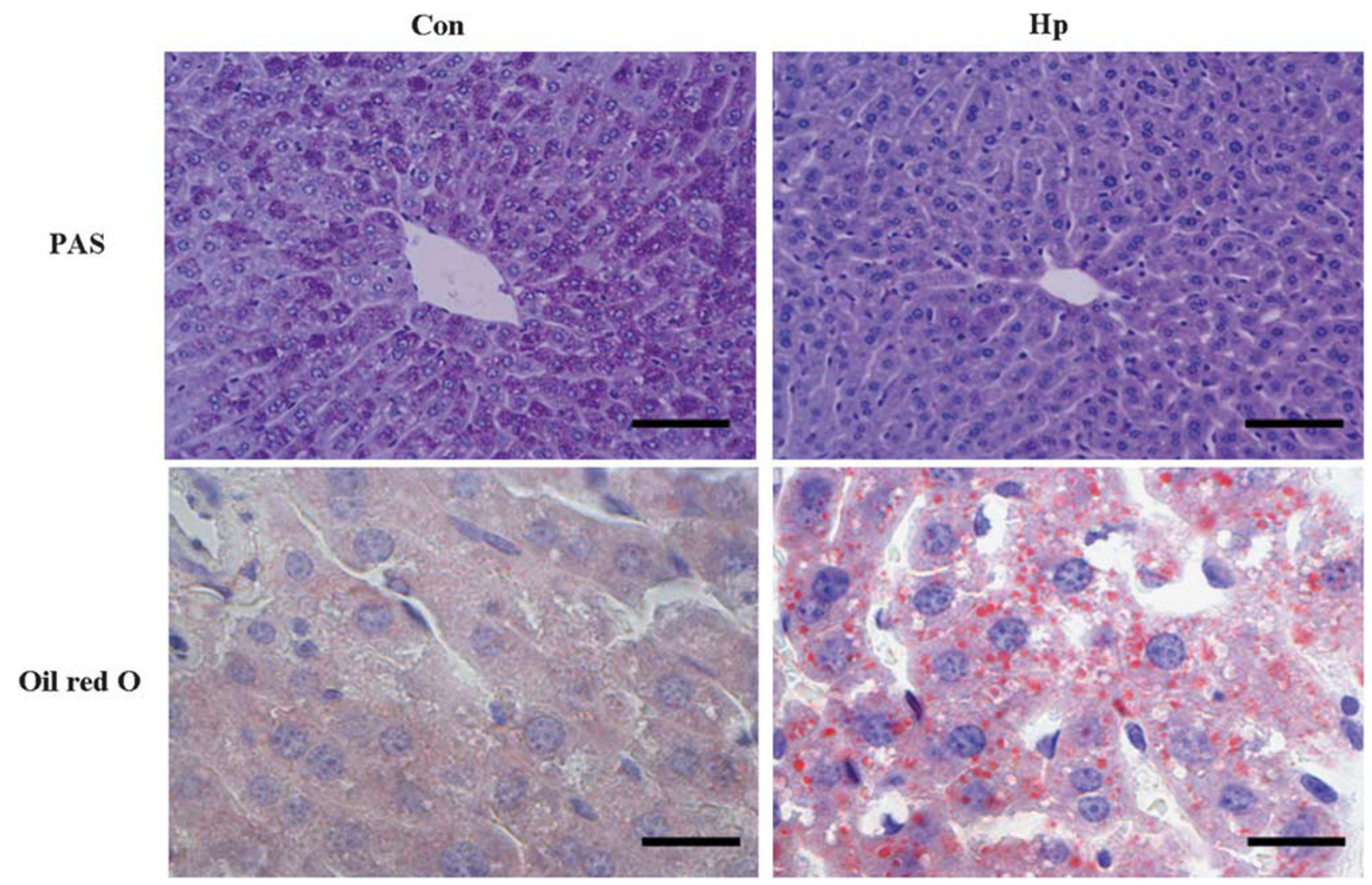

Figure 8 Histopathological changes by H. pylori infection in the mouse liver tissues stained by PAS and oil-red O staining. To observe the location of hepatic glycogen granules and the glycogen density of hepatocytes, PAS stain was used. The noninfected liver stained with PAS visualized the densely deposited glycogen as purple granules in hepatocyte cytoplasm. Scale bar, $50 \mu \mathrm{m}$. In the $\mathrm{H}$. pylori-infected liver, glycogen storage was remarkably reduced compared with the noninfected liver. To differentiate intracellular vacuoles and lipid accumulation, a frozen section of the liver was stained with oil-red 0 . The noninfected liver stained with oil-red $O$ showed several hepatocytes containing positively few lipid droplets. The $H$. pylori-infected liver showed increased number of small lipid droplets (red) in hepatocytes. Scale bar, $20 \mu \mathrm{m}$.

Therefore, oxidative stress has been reported to modulate collagen gene expression. ${ }^{33}$ Furthermore, hepatic tissue damage concurrent with pathogenic infection in the liver may increase the synergistic effect of oxidative stress in the pathogenesis of hepatic injury.

SMP30 has been known as a multifunctional protein, highly expressed in hepatocytes, preventing oxidative stress and cellular apoptosis. ${ }^{16,34}$ Jung et al proposed that increased oxidative status by LPS-treatment, well known to increase oxidative stress, causes downregulation of the SMP30 gene expression. ${ }^{40}$ Decrease in SMP30 expression in this study provides the possibility that LPS originating from $H$. pylori could reach the liver and result in oxidative stress. Ishigami et $a l^{35}$ suggested that susceptibility to harmful stimuli markedly increases, when SMP30 expression in the liver decreases due to continuous oxidative stress.

This is the first in vivo study to investigate the association between the presence of $H$. pylori DNA in the liver and hepatic fibrosis. Our study also successfully detected Helicobacter genomic materials in the mouse liver as well as showed that most $H$. pylori-infected animals had specific antibodies in both experimental species (Table 2). One study demonstrated that immunostaining for $\mathrm{H}$. pylori and electron microscopy showed morphologically intact bacteria in one patient with primary sclerosing cholangitis, ${ }^{36}$ and Wang et $\mathrm{al}^{13}$ demonstrated the presence of $H$. pylori bacteria inside the HCC tissue by immunohistochemical stain for $H$. pylori. In addition, the study by Francavilla $e t a l,{ }^{37}$ which stated that vacuolating toxin A (VacA), one of the bacterial virulence factors, was detected in hepatocytes of patients with isolated hypertransaminasemia supports the report that transaminases in humans infected by cytotoxic strains of $H$. pylori increase mildly. ${ }^{38}$ In this study, we ascertained bacterial fragments by immunostaining for $H$. pylori in $H$. pylori-infected liver tissues. These data strongly support those of previous studies that $H$. pylori DNA and/or protein could reach the liver.

Finally, chronic $H$. pylori infection could have a crucial role as a co-risk factor for exacerbation of liver fibrosis under exogenous oxidative stimuli as well as being an independent troublemaker causing dysfunction in the livers of rodent animals. In addition, our findings indicate that influence of 
H. pylori on hepatopathy is not only restricted to cytotoxic strain, ATCC 43504 (VacA, s1m1) but also to the SS1 (VacA, $\mathrm{s} 2 \mathrm{~m} 2$ ) strain which shows no vacuolating cytotoxic activity. ${ }^{39}$ A possible explanation for this finding may be that another pathological factor from $H$. pylori causing oxidative stress besides cytotoxic VacA may participate in the pathogenesis of liver fibrosis.

Nonetheless, this study has a limitation to directly relate to the pathophysiological situation in humans. In humans, $H$. pylori infection is usually acquired in early childhood and results in the majority of subjects having chronic persistent gastritis with the establishment of equilibrium between the host and germ. Liver damage (alcohol or virus induced) occurs decades later, when a 'balanced gastritis' is present in subjects. Therefore, we speculate that it is difficult to totally relate to human condition, as the duration of $\mathrm{H}$. pylori infection that lasts for several weeks in the hepatic fibrosisinduced animal models of this study is short to link to the pathophysiological situation of the humans. Further in vitro and in vivo studies are still necessary to delineate the precise mechanisms underlying the pathogenesis of $H$. pylori-related liver fibrosis in humans.

\section{ACKNOWLEDGEMENT}

This research was supported by a grant (code: CBM 31-B3003-01-01-00) from the Center for Biological Modulators of the 21st Century Frontier R\&D Program, the Ministry of Science and Technology, Korea.

\section{DISCLOSURE/CONFLICT OF INTEREST}

The authors declare no conflict of interest.

1. Crowe SE. Helicobacter infection, chronic inflammation, and the development of malignancy. Curr Opin Gastroenterol 2005;21:32-38.

2. Stalke $P$, Zoltowska A, Orlowski $M$, et al. Correlation between liver damage and degree of gastric mucosae colonisation by Helicobacter pylori in subjects with parenchymatous liver damage. Med Sci Monit 2001;7(Suppl):271-276.

3. Pellicano R, Leone $\mathrm{N}$, Berrutti $\mathrm{M}$, et al. Helicobacter pylori seroprevalance in hepatitis $C$ virus positive patients with cirrhosis. J Hepatol 2000;33:648-650.

4. Fox JG, Drolet R, Higgins R, et al. Helicobacter canis isolated from a dog liver with multifocal necrotizing hepatitis. J Clin Microbiol 1996;34:2479-2482.

5. Ponzetto A, Pellicano R, Redaelli A, et al. Helicobacter pylori infection in patients with hepatitis $C$ virus positive chronic liver diseases. New Microbiol 2003;26:321-328.

6. Ponzetto A, Pellicano R, Leone $\mathrm{N}$, et al. Helicobacter pylori seroprevalence in cirrhotic patients with hepatitis B virus infection. Neth J Med 2000;56:206-210.

7. Calvet $X$, Navarro M, Gil M, et al. Seroprevalence and epidemiology of Helicobacter pylori infections in patients with cirrhosis. J Hepatol 1997:26:1249-1254.

8. Nilsson H-O, Taneera J, Castedal M, et al. Identification of Helicobacter pylori and other Helicobacter species by PCR, hybridization, and partial DNA sequencing in human liver samples from patients with primary sclerosing cholangitis or primary biliary cirrhosis. Clin Microbiol 2000;38:1072-1076

9. Avenaud P, Marais A, Monteiro L, et al. Detection of Helicobacter species in the liver of patients with and without primary liver carcinoma. Cancer 2000;89:1431-1439.

10. Desmet VJ, Roskams T. Cirrhosis reversal: a duel between dogma and myth. J Hepatol 2004;40:860-867.
11. George J, Tsutsumi M, Takase S. Expression of hyaluronic acid in $\mathrm{N}$ nitrosodimethylamine induced hepatic fibrosis in rats. Int J Biochem Cell Biol 2004;36:307-319.

12. Tian XF, Fan XG, Fu CY, et al. Experimental study on the pathological effect of Helicobacter pylori on liver tissues. Zhonghua Gan Zang Bing Za Zhi 2005;13:780-783.

13. Wang $X$, Willen $R$, Svensson M, et al. Two-year follow-up of Helicobacter pylori infection in C57BL/6 and Balb/cA mice. APMIS 2003;111:514-522.

14. Taylor NS, Fox JG, Yan L. In-vitro hepatotoxic factor in Helicobacter hepaticus, H. pylori and other Helicobacter species. J Med Microbiol 1995;42:48-52.

15. Chen R, Fan XG, Huang $Y$, et al. In vitro cytotoxicity of Helicobacter pylori on hepatocarcinoma HepG2 cells. Ai Zheng 2004;23:44-49.

16. Lee A, O'Rourke J, De Ungria MC, et al. A standardized mouse model of Helicobacter pylori infection: introducing the Sydney strain. Gastroenterology 1997;112:1386-1397.

17. Fu Y, Zheng S, Lin J, et al. Curcumin protects the rat liver from $\mathrm{CCl}_{4}{ }^{-}$ caused injury and fibrogenesis by attenuating oxidative stress and suppressing inflammation. Mol Pharmacol 2008;73:399-409.

18. Oriya $K$, Yoshikawa $M$, Ouji $Y$, et al. Embryonic stem cells reduce liver fibrosis in $\mathrm{CCl}_{4}$-treated mice. Int J Exp Pathol 2008;89:401-409.

19. Zubakhin AA, Kutina SN, Maianski DN. Functional state of the hematopoietic system in different stages of $\mathrm{CCL}_{4}$-induced liver fibrosis in mice. Biull Eksp Biol Med 1992;114:22-24.

20. Mendler MH, Yashar B, Govindarajan S, et al. A novel semi-quantitative histological scoring system for nonalcoholic fatty liver disease: evaluation and clinical correlations. Hepatology 2002;36:407A.

21. Jeong DH, Lee GP, Jeong WI, et al. Alterations of mast cells and TGFbeta1 on the silymarin treatment for $\mathrm{CCl}_{4}$ )-induced hepatic fibrosis. World J Gastroenterol 2005;11:1141-1148.

22. Goo MJ, Ki MR, Lee HR, et al. Primary biliary cirrhosis, similar to that in human beings, in a male C57BL/6 mouse infected with Helicobacter pylori. Eur J Gastroenterol Hepatol 2008;20:1045-1048.

23. Carmiel-Haggai M, Cederbaum Al, Nieto N. A high-fat diet leads to the progression of non-alcoholic fatty liver disease in obese rats. FASEB J 2005;19:136-138.

24. Powell EE, Jonsson JR, Clouston AD. Steatosis: co-factor in other liver diseases. Hepatology 2005;42:5-13.

25. Jeong WI, DO SH, Kim TH, et al. Acute effects of fast neutron irradiation on mouse liver. J Radiat Res (Tokyo) 2007;48:233-240.

26. Abdel-Hady $\mathrm{H}$, Zaki A, Badra G, et al. Helicobacter pylori infection in hepatic encephalopathy: relationship to plasma endotoxins and blood ammonia. Hepatol Res 2007;37:1026-1033.

27. Engin $A$, Zemheri $M$, Bukan $N$, et al. Effect of nitric oxide on the hypoglycaemic phase of endotoxaemia. ANZ J Surg 2006;76:512-517.

28. Berry LJ, Smythe DS, Young LG. Effects of bacterial endotoxin on metabolism. I. Carbohydrate depletion and the protective role of cortisone. J Exp Med 1959;110:389-405.

29. Tahashi Y, Matsuzaki K, Date M, et al. Differential regulation of TGFbeta signal in hepatic stellate cells between acute and chronic rat liver injury. Hepatology 2002;35:49-61.

30. Dooley S, Hamzavi J, Breitkopf $K$, et al. Smad7 prevents activation of hepatic stellate cells and liver fibrosis in rats. Gastroenterology 2003;125:178-191.

31. Slater TF, Sawyer BC. The stimulatory effects of carbon tetrachloride and other halogenoalkanes on peroxidative reactions in rat liver fractions in vitro. General features of the systems used. Biochem J 1971;123:805-814.

32. Svegliati Baroni G, D'Ambrosio L, Ferretti G, et al. Fibrogenic effect of oxidative stress on rat hepatic stellate cells. Hepatology 1998;27:720-726.

33. Casini $A$, Cunningham $M$, Rojkind $M$, et al. Acetaldehyde increases procollagen type I and fibronectin gene transcription in cultured rat fat-storing cells through a protein synthesis-dependent mechanism. Hepatology 1991;13:758-765.

34. Sar P, Rath B, Subudhi U, et al. Alterations in expression of senescence marker protein-30 gene by 3,3,5-triiodo-L: -thyronine $(T(3))$. Mol Cell Biochem 2007;303:239-242.

35. Ishigami $A$, Fujita $T$, Handa $S$, et al. Senescence marker protein-30 knockout mouse liver is highly susceptible to tumor necrosis factoralpha- and Fas-mediated apoptosis. Am J Pathol 2002;161:1273-1281.

36. Wadström $T$, Ljungh A, Willén R. Primary biliary cirrhosis and primary sclerosing cholangitis are of infectious origin!. Gut 2001;49:454. 
37. Francavilla $A$, lerardi $E$, Francavilla $R$, et al. Immunohistochemical detection of Helicobacter pylori vacuolating cytotoxin in the hepatocytes of patients with isolated hypertransaminasaemia. Ital J Gastroenterol Hepatol 1999;3:675-676.

38. Figura N. Hypothesis: Helicobacter toxins and liver. Helicobacter 1996;1:187-189.
39. Day AS, Jones NL, Policova Z, et al. Characterization of virulence factors of mouse-adapted Helicobacter pylori strain SS1 and effects on gastric hydrophobicity. Dig Dis Sci 2001:46:1943-1951.

40. Jung KJ, Ishigami $\mathrm{A}$, Maruyama $\mathrm{N}$, et al. Modulation of gene expression of SMP-30 by LPS and calorie restriction during aging process. Exp Gerontol 2004;39:1169-1177. 